\title{
PENGARUH STRATEGI PEMBELAJARAN DAN KEPRIBADIAN TERHADAP HASIL BELAJAR KOGNITIF DAN AFEKTIF PENDIDIKAN KEWARGANEGARAAN MAHASISWA JURUSAN PPKn FIS UNIMED
}

Oleh :

Sri Yunita*

\begin{abstract}
Abstrak
Penelitian ini dilaksanakan di Fakultas Ilmu Sosial Universitas Negeri Medan. Metode yang digunakan dalam penelitian ini adalah metode eksperimen dengan desain Faktorial 2 x 4. Berdasarkan data yang diperoleh, hasil pengujian hipotesis pertama, tidak terdapat perbedaan hasil belajar PKn mahasiswa yang dibelajarkan dengan strategi pembelajaran berbasis masalah dan strategi pembelajaran kooperatif tipe team game tournament. Hipotesis Kedua, terdapat perbedaan hasil belajar PKn mahasiswa yang memiliki kepribadian koleris, sanguine, phlegmatic dan melankolis. Hipetesis ketiga, tidak terdapat interaksi antara strategi pembelajaran dan kepribadian dalam mempengaruhi hasil belajar.
\end{abstract}

Kata Kunci: Hasil Belajar, Strategi Pembelajaran, Pembelajaran Berbasis Masalah, Pembelajaran Kooperatif, Kepribadian

\section{A. Pendahuluan}

Tujuan pendidikan mengisyaratkan bahwa pendidikan adalah untuk membentuk karakter bangsa. Salah satu usaha yang ditempuh pemerintah untuk mewujudkannya adalah dengan memasukkan Pendidikan Kewarganegaraan (PKn) sebagai mata pelajaran wajib di sekolah. Sayangnya, PKn yang dipelajari mulai dari tingkat SD hingga perguruan tinggi ini juga belum memberikan dampak yang signifikan terhadap pembentukan karakter generasi bangsa.

PKn sebagai pendidikan politik dan moral bangsa adalah sebuah keniscayaan yang tak bisa ditawar untuk tetap eksis dan maju ke arah paradigma baru. Menurut Malik Fajar (2004:4) sejak tahun 1994, pembelajaran PKn menghadapi berbagai kendala dan keterbatasan. Kendala dan keterbatasan tersebut adalah: (1) masukan instrumental terutama yang berkaitan dengan kualitas guru serta keterbatasan fasilitas dan sumber belajar, dan (2) masukan lingkungan terutama yang berkaitan dengan kondisi dan situasi kehidupan politik negara yang kurang demokratis.

Beberapa petunjuk empiris menyangkut permasalahan tersebut antara lain sebagai berikut. Pertama, proses pembelajaran

\footnotetext{
${ }^{*}$ Dosen Jurusan Pendidikan Geografi, Fakultas Ilmu Sosial, UNIMED
} 
dan penilaian lebih menekankan pada aspek instruksional yang sangat terbatas, yaitu pada penguasaan materi. Dengan kata lain lebih menekankan pada dimensi kognitifnya sehingga telah mengabaikan sisi lain yang penting, yaitu pembentukan watak dan karakter yang sesungguhnya menjadi fungsi dan tujuan utama Ilmu Pengetahuan Sosial (IPS). Kedua, pengelolaan kelas belum mampu menciptakan suasana yang kondusif untuk berkembangnya pengalaman belajar peserta didik yang dapat menjadi landasan untuk berkembangnya kemampuan intelektual peserta didik.

Untuk itu sangat penting untuk membangun model-model pembelajaran khususnya dalam Ilmu Pengetahuan Sosial (IPS) dalam rangka, menciptakan proses belajar yang menyenangkan, mengasyikkan, sekaligus mencerdaskan. Salah satu usaha yang dapat dilakukan pendidik untuk meningkatkan motivasi mahasiswa untuk belajar dan menggali lebih lanjut pengetahuan yang diperolehnya sekaligus mampu mengaitkan pengetahuan yang diperolehnya dengan kehidupan nyata adalah menerapkan strategi Pembelajaran Berbasis Masalah (PBM) dan kooperatif. Kedua strategi tersebut menuntut peran lebih peserta didik dalam proses pembelajaran. Peserta didik berperan aktif dan dilatih untuk memecahkan permasalahan dan berpikir rasional, baik secara individu maupun kelompok.

Selain faktor strategi pembelajaran yang berasal dari luar diri peserta didik, ada faktor yang berasal dari dalam diri peserta didik yang juga berpengaruh dalam proses pembelajaran. Salah satu adalah karakter peserta didik. Uno (2006:143) menjelaskan bahwa karakteristik mahasiswa merupakan salah satu hal yang perlu diidentifikasi oleh guru untuk digunakan sebagai petunjuk dalam mengembangkan program pembelajaran. Karakteristik yang diidentifikasi tersebut dapat berupa bakat, motivasi, gaya belajar, kemampuan berfikir, minat sikap, kemampuan awal, kecerdasan, kepercayaanan diri, konsep diri, efikasi diri, kepribadian dan sebagainya. Kepribadian sebagai ciri karakteristik seseorang merupakan faktor yang berpengaruh terhadap diri seseorang dalam bertindak, mengambil keputusan, berkomunikasi dengan orang lain, berpikir, dan belajar. Banyak teori kepribadian yang dijabarkan oleh banyak ahli psikologi yang sebagian teori memiliki kemirPKnn dengan teori yang lain. Salah satu teori kepribadian yang sudah cukup dikenal adalah teori kepribadian yang diteorikan oleh Galen, seorang ahli fisiolog Romawi yang hidup di abad ke-2 Masehi.

Galen menyatakan bahwa kepribadian manusia bisa dibagi menjadi empat kelompok besar: sanguin (populer), koleris (kuat), melankolis (sempurna), dan phlegmatis (damai). Meski teori ini 
tergolong sangat kuno, para psikolog masa sekarang mengakui, teori kepribadian ini banyak benarnya.

\section{B. Metode Penelitian}

Penelitian ini digolongkan penelitian quasi eksperimen dengan desain faktorial $2 \mathrm{x} 4$. Penelitian ini melibatkan 2 kelompok sampel yang ditetapkan sebagai kelompok eksperimen. Kelompok eksperimen masing-masing diberlakukan strategi PBM dan strategi kooperatif tipe TGT.

Secara umum desain penelitian ini menggunakan rancangan faktorial desain $2 \times 4$, melalui disain ini akan dilihat pengaruh strategi pembelajaran dan kepribadian terhadap hasil belajar PKn dapat digambarkan sebagai berikut:

Tabel 1. Rancangan Eksperimen Disain Faktorial 2 x 4

\begin{tabular}{|c|c|c|}
\hline \multirow{2}{*}{ Kepribadian $(\mathrm{B})$} & \multicolumn{2}{|c|}{ Strategi Pembelajaran $(\mathrm{A})$} \\
\cline { 2 - 3 } & PBM $\left(\mathrm{A}_{1}\right)$ & Kooperatif tipe TGT $\left(\mathrm{A}_{2}\right)$ \\
\hline Koleris $\left(\mathrm{B}_{1}\right)$ & $\mathrm{A}_{1} \mathrm{~B}_{1}$ & $\mathrm{~A}_{2} \mathrm{~B}_{1}$ \\
\hline Sanguin $\left(\mathrm{B}_{2}\right)$ & $\mathrm{A}_{1} \mathrm{~B}_{2}$ & $\mathrm{~A}_{2} \mathrm{~B}_{2}$ \\
\hline Phlegmatis $\left(\mathrm{B}_{3}\right)$ & $\mathrm{A}_{1} \mathrm{~B}_{3}$ & $\mathrm{~A}_{2} \mathrm{~B}_{3}$ \\
\hline Melankolis $\left(\mathrm{B}_{4}\right)$ & $\mathrm{A}_{1} \mathrm{~B}_{4}$ & $\mathrm{~A}_{2} \mathrm{~B}_{3}$ \\
\hline
\end{tabular}

Sebelum dilakukan perlakuan terlebih dahulu ditinjau faktor-faktor kesamaan dari kedua kelompok eksperimen yaitu kesamaan dalam faktor-faktor yang mempengaruhi pelaksanaan kegiatan pembelajaran. Hal ini dilakukan dengan maksud untuk meyakinkan kedua kelompok eksperimen mempunyai karakteristik yang dianggap sama, kecuali faktor perlakuan strategi pembelajaran. Faktor-faktor yang dapat mempengaruhi kegiatan pembelajaran antara lain adalah faktor tujuan pembelajaran, dosen, situasi, kondisi kelas dan metode mengajar.

Mahasiswa yang menjadi sampel penelitian ini mempunyai kesamaan yaitu sama-sama belajar di semester yang sama, pada jam pelajaran yang sama, situasi lingkungan dan kondisi mahamahasiswa pada saat belajar juga dianggap sama karena mereka mempunyai rata-rata usia yang hampir sama dan mengalami perlakuan yang sama satu sama lain.

\section{Hasil dan Pembahasan}

\section{Tipe Kepribadian Mahasiswa}

Kelompok mahasiswa di kelas PBM yang bertipe kepribadian koleris berjumlah $25 \%$, phlegmatis $22,5 \%$, sanguin $30 \%$ dan melankolis $22,5 \%$. Sedangkan untuk kelas TGT yang bertipe kepribadian koleris $25 \%$, phlegmatis $27,5 \%$, sanguin $25 \%$ dan melankolis $22,5 \%$. 
Selanjutnya, dapat dikelompokkan data hasil belajar mahasiswa berdasarkan kelas perlakuan dan tipe kepribadian sebagai berikut:

Deskripsi data penelitian hasil belajar PKn mahasiswa mencakup hasil belajar secara keseluruhan, berupa nilai maksimum, nilai minimum, mean, modus, median, standar deviasi dan varians dianalisis dengan bantuan program SPSS versi 17.0.

\section{Pengujian Hipotesis}

Pengujian hipotesis menggunakan bantuan program SPSS dengan rangkuman hasil sebagai berikut :

\begin{tabular}{|l|r|r|}
\hline Kelompok & \multicolumn{1}{|c|}{ F } & \multicolumn{1}{c|}{ Sig. } \\
\hline Strategi Pembelajaran & 2.952 & .090 \\
Tipe Kepribadian & 14.129 & .000 \\
Interaksi Strategi dan Kepribadian & .406 & .749 \\
\hline
\end{tabular}
2,952 dan $\quad p=0,090$ dengan $\alpha=0.05$. Hasil ini menunjukkan bahwa $\mathrm{P}=0.00>\alpha=0.05$ sehingga Hipotesis $\mathrm{Nol}\left(\mathrm{H}_{0}\right)$ gagal ditolak dan Hipotesis alternatif (Ha) ditolak, sehingga dapat disimpulkan bahwa tidak terdapat perbedaan yang signifikan antara hasil belajar PKn mahasiswa yang dibelajarkan dengan strategi PBM dan yang dibelajarkan dengan strategi TGT.

Berdasarkan hasil perhitungan diketahui bahwa hasil belajar mahasiswa yang dibelajarkan dengan strategi pembelajaran PBM hanya rata-rata lebih tinggi 3,22\% lebih tinggi dibanding dengan dan dibelajarkan dengan strategi pembelajaran Kooperatif tipe TGT.

Berdasarkan hasil pengujian hipotesis diperoleh $\mathrm{F}_{\text {hitung }}=$ 14,129 dan $\mathrm{p}=0.00$ dengan $\alpha=0.05$. Hasil ini menunjukkan bahwa $\mathrm{P}=0.00<\alpha=0.05$. Sehingga Hipotesis Nol (Ho) ditolak dan Hipotesis alternatif (Ha) gagal ditolak, dengan demikian hipotesis penelitian yang menyatakan bahwa minimal satu dari kelompok mahasiswa yang memiliki kepribadian Koleris, Sanguin, Phlegmatis dan Melankolis memperoleh hasil belajar PKn berbeda teruji kebenarannya.

Untuk mengetahui dengan pasti kelompok mahasiswa dengan kepribadian yang mana yang berbeda dengan kelompok lainnya, maka dilakukan uji lanjut dengan menggunakan uji Scheffe karena jumlah sampel tiap kelompok berbeda.

Kriteria penerimaan jika : $p<\alpha=0.05$, maka teruji secara signifikan. Berdasarkan hasil uji Scheffe pada Tabel 3. di atas dapat dilihat bahwa terdapat 6 (enam) pasang hipotesis statistik, yakni : 
a. Dari hasil perhitungan dengan menggunakan uji Scheffe menunjukkan bahwa $\mathrm{p}=0.578>\alpha=0.05$, sehingga memberikan keputusan menerima Ho. Dengan demikian, dapat disimpulkan bahwa tidak terdapat perbedaan hasil belajar PKn mahasiswa yang memiliki kepribadian koleris dan sanguin.

b. Dari hasil perhitungan dengan menggunakan uji Scheffe menunjukkan $\mathrm{p}=0.00<\alpha=0.05$, sehingga memberikan keputusan menolak Ho. Dengan demikian, dapat disimpulkan bahwa terdapat perbedaan antara hasil belajar PKn mahasiswa yang memiliki kepribadian koleris dan phlegmatis.

c. Dari hasil perhitungan dengan menggunakan uji Scheffe menunjukkan $\mathrm{p}=0.621>\alpha=0.05$, sehingga memberikan keputusan menerima Ho. Dengan demikian, dapat disimpulkan bahwa tidak terdapat perbedaan antara hasil belajar PKn mahasiswa yang memiliki kepribadian koleris dan melankolis.

d. Dari hasil perhitungan dengan menggunakan uji Scheffe menunjukkan $\mathrm{p}=0.00<\alpha=0.05$, sehingga memberikan keputusan menolak Ho. Dengan demikian, dapat disimpulkan bahwa terdapat perbedaan hasil belajar PKn mahasiswa yang memiliki kepribadian sanguin dan phlegmatis.

e. Dari hasil perhitungan dengan menggunakan uji Scheffe menunjukkan $p=0.012<\alpha=0.05$, sehingga memberikan keputusan menolak Ho. Dengan demikian, dapat disimpulkan bahwa terdapat perbedaan antara hasil belajar PKn mahasiswa yang memiliki kepribadian melankolis dan phlegmatis.

f. Dari hasil perhitungan dengan menggunakan uji Scheffe menunjukkan $\mathrm{p}=0,067>\alpha=0.05$, sehingga memberikan keputusan menerima Ho. Dengan demikian dapat disimpulkan bahwa tidak terdapat perbedaan hasil belajar PKn mahasiswa yang memiliki kepribadian melankolis dan sanguin.

Berdasarkan hasil pengujian hipotesis di atas diperoleh perhitungan interaksi strategi pembelajaran dengan kepribadian, dimana $\mathrm{F}_{\text {hitung }}=0,406$ dan $\mathrm{P}=0.749$ dengan $\alpha=0.05$. Hasil ini menunjukkan bahwa $\mathrm{P}=0,794>\alpha=0.05$ sehingga Hipotesis Nol (Ho) gagal ditolak sehingga disimpulkan bahwa tidak terdapat interaksi antara strategi pembelajaran dan kepribadian dalam mempengaruhi hasil belajar PKn mahasiswa.

Berdasarkan pengujian hipotesis pertama diperoleh kesimpulan bahwa tidak ada perbedaan hasil belajar PKn mahasiswa yang dibelajarkan dengan strategi PBM dan strategi Kooperatif tipe TGT.

Banyak faktor yang dapat mempengaruhi hasil belajar mahasiswa. Faktor tersebut dapat berasal dari diri mahasiswa sendiri seperti kepribadian dan dapat juga berasal dari luar diri 
mahasiswa seperti strategi pembelajaran yang dirancang oleh dosen. Strategi pembelajaran perlu dirancang dengan baik agar efektif dan efisien dalam mencapai tujuan pembelajaran. Oleh karena itu, seorang dosen perlu memperhatikan beberapa hal sebagai pertimbangan untuk merancang strategi pembelajaran.

Dalam penelitian ini strategi pembelajaran PBM dan strategi pembelajaran Kooperatif tipe TGT memberikan pengaruh yang tidak berbeda secara signifikan terhadap hasil belajar. Perbedaan rata-rata hasil belajar yang diperoleh hanya sedikit. Dilihat dari karakteristik masing-masing strategi, kedua strategi ini memiliki karakteristik yang hampir serupa yaitu menitikberatkan pada pemecahan masalah baik secara individu maupun kelompok.

Metode yang digunakan pada tahapan pembelajaran pada kedua strategi juga hampir serupa misalnya, pemecahan masalah, membagi kelas dalam kelompok, menyelesaikan permasalahan dengan diskusi dalam kelompok, presentasi hasil diskusi dalam kelas, dan tanya jawab. Perbedaan kedua strategi ada pada proses diskusi dalam kelompok dan tahap evaluasi dan refleksi di akhir pembelajaran. Proses diskusi pada strategi PBM lebih sistematis, karena tahapan-tahapan dalam menyelesaikan masalah di dalam kelompok sudah diatur dan dibimbing oleh dosen. Sedangkan pada strategi kooperatif kelompok diberi kebebasan memilih cara untuk menyelesaikan permasalahan sendiri. Selain itu, diakhir pembelajaran kooperatif tipe TGT mahasiswa diberi games untuk menguji penguasaan terhadap materi yang dipelajari, sedangkan pada strategi PBM tidak.

Selanjutnya berdasarkan analisis anava kepribadian terhadap hasil belajar PKn diperoleh bahwa terdapat perbedaan hasil belajar PKn mahasiswa yang memiliki gaya belajar koleris, sanguin, phlegmatis dan melankolis. Lebih tepatnya dapat dijabarkan sebagai berikut : 1) terdapat perbedaan hasil belajar PKn mahasiswa yang memiliki kepribadian koleris dan phlegmatis, 2) terdapat perbedaan hasil belajar PKn mahasiswa yang memiliki kepribadian sanguin dan phlegmatis, dan 3) terdapat perbedaan hasil belajar PKn mahasiswa yang memiliki kepribadian melankolis dan phlegmatis. Akan tetapi tidak terdapat perbedaan hasil belajar mahasiswa yang memiliki kepribadian koleris dan sanguin, demikian pula tidak terdapat perbedaan hasil belajar mahasiswa yang memiliki kepribadian sanguin dan melankolis. Selanjutnya tidak terdapat perbedaan hasil belajar mahasiswa yang memiliki kepribadian melankolis dan koleris.

Dapat dijelaskan bahwa perbedaan hasil belajar hanya terjadi antara mahasiswa yang memiliki kepribadian phlegmatis dengan tiga tipe kepribadian lainnya. Tipe kepribadian phlegmatis 
cenderung memperoleh rata-rata hasil belajar yang lebih rendah dibanding dengan tipe kepribadian lainnya. Mahasiswa dengan tipe kepribadian phlegmatis di dalam kelas cenderung pasif sesuai dengan tipenya yang pembawaannya tenang dan cenderung sulit dimotivasi. Tipe phlegmatis juga cenderung enggan mencoba halhal baru dan ingin selalu berada di "zona aman" mereka. Tidak ingin terlalu terlihat menonjol meskipun cukup bisa beradaptasi dan mudah diajak bekerjasama. Sifat pasif seperti ini membuat mahasiswa dengan tipe phlegmatis tidak menonjol di dalam kelas, mau berdiskusi tetapi keberatan jika diminta menjadi moderator atau sekedar menanggapi pertanyaan dari kelompok lain.

Sedangkan tipe kepribadian lain, koleris, sanguin dan melankolis memperoleh rata-rata hasil belajar yang selisihnya tidak terlalu jauh. Dari ketiga kepribadian ini, sanguin memperoleh rata-rata hasil belajar yang cenderung lebih tinggi dibanding dua kepribadian lainnya. Tipe kepribadian sanguin memiliki kepribadian yang terbuka, sangat ramah, suka tampil dan terlihat menonjol, dalam berdiskusi terlihat menonjol dan dengan senang hati menerima bila diminta menjadi moderator atau memimpin diskusi meskipun tidak terlalu menguasai permasalahan. Tipe ini juga cenderung aktif dan tidak bisa diam. Sangat menyukai tantangan sehingga sangat aktif mengikuti permainan.

Selanjutnya tipe kepribadian koleris, tipe ini suka memimpin, tipe yang selalu merasa dirinya benar, dalam kelompok sering dijadikan ketua dan sering memimpin diskusi. Cenderung dominan dalam kelompok dan sulit dipatahkan pendapatnya. Sangat baik memimpin kelompok dalam menyelesaikan permasalahan. Meskipun terkadang terlihat ingin menang sendiri dan tidak mau mempertimbangkan pendapat orang lain.

Tipe lainnya adalah melankolis, tipe ini suka berpikir, sangat perfeksionis dan memperhatikan hal-hal yang detil. Meskipun tidak terlalu peduli dengan menjadi menonjol atau tidak di dalam kelompok dan kelas, tipe ini tetap bisa mengikuti pelajaran dengan baik karena tipe ini cenderung lebih cerdas secara kognitif dibanding dengan tipe lain. Hal ini mungkin disebabkan karena tipe ini tipe serius dan konsentrasinya tidak gampang dialihkan dengan hal-hal kecil.

Hasil hipotesis selanjutnya adalah tidak terdapat interaksi antara strategi pembelajaran dan kepribadian dalam mempengaruhi hasil belajar mahasiswa. Hal ini dapat dijelaskan bahwa setiap kepribadian memiliki perilaku yang hampir serupa di masingmasing kelas, baik di kelas PBM maupun kelas TGT. Karena kedua strategi pembelajaran juga memiliki karakteristik yang 
hampir serupa, sehingga masing-masing kepribadian juga tidak ada yang diuntungkan atau dirugikan dari masing-masing strategi.

\section{Kesimpulan}

Berdasarkan hasil penelitian ini, maka dapat ditarik kesimpulan sebagai berikut :

1. Tidak terdapat perbedaan hasil belajar PKn mahasiswa yang dibelajarkan strategi pembelajaran PBM dan strategi kooperatif tipe TGT

2. Terdapat perbedaan hasil belajar PKn mahasiswa yang memiliki kepribadian koleris dan phlegmatis

3. Terdapat perbedaan hasil belajar PKn mahasiswa yang memiliki kepribadian sanguin dan phlegmatis

4. Terdapat perbedaan hasil belajar PKn mahasiswa yang memiliki kepribadian melankolis dan phlegmatis

5. Tidak terdapat perbedaan hasil belajar PKn mahasiswa yang memiliki kepribadian sanguin dan koleris

6. Tidak terdapat perbedaan hasil belajar PKn mahasiswa yang memiliki kepribadian sanguin dan melankolis

7. Tidak terdapat perbedaan hasil belajar PKn mahasiswa yang memiliki kepribadian koleris dan melankolis

8. Tidak terdapat interaksi antara strategi pembelajaran dan kepribadian dalam mempengaruhi hasil belajar PKn mahasiswa

\section{Daftar Pustaka}

Anderson, O.W, Krathwohl, D.R. (2001). A Taxonomy for Learning, Teaching, and Assessing. New York: Addison Wesley Longman, Inc

Arends, Richard L, 2008, Learning to Teach. Yogyakarta. Pustaka Pelajar

Arikunto, Suharsimi. (2005). Manajemen Penelitian, Jakarta: Rineka Cipta.

Arikunto, Suharsimi. (2008). Dasar-Dasar Evaluasi Pendidikan, Jakarta: Bumi Aksara

Ausubel, D.P.. (1986). Educational Physichology: A Cognitive View. New York: Holt Rinehart \& Winston

Bigge, Morris L. (1982). Learning Theories For Teachers. New York: Harper \& Row

Dick, W \& Carey, L. (2005). The Systematic Design of Instrustional. New York: Longman

Dimyati. (1994). Belajar dan Pembelajaran, Jakarta: Rineka Cipta Gerlach, Vernon S \& Ely, Donald P. (1980). Teaching \& Media, A Systematic Approach. New Jersey: Prentice Hall 
Kirby, John R. (1984). Cognitif Strategies and Educational Performance. London: Academic Press. Inc

Miarso, Yusufhadi. (2007). Menyemai Benih Teknologi Pendidikan. Jakarta: Kencana

Prawiradilaga, Dewi Salma. (2008). Prinsip Disain Pembelajaran. Jakarta: Kencana

Reigeluth, C. M. (1983). Instructional Design Theory of Models: An Overview of Their Current Status. London: Prentice Hall

Romiszwoski, A.J. (1981). Instructional Design System, Decision Making in Course Planning and Curriculum Design. London: Kogan

Sanjaya, Wina. (2008). Strategi Pembelajaran. Jakarta: Kencana Slavin, R. 1995. Cooperative Learning. Boston : Allyn \& Bacon Uno, Hamzah B. (2008). Orientasi Baru dalam Psikologi Pembelajaran. Jakarta: Bumi Aksara

Winkel, W.S. (1996). Psikologi Pengajaran. Jakarta: Gramedia

Widiasarana Indonesi 
